\title{
Surgical Treatment of Liver Metastases of Gynecological Cancer: Local Treatment of a Systemic Disease
}

\author{
Eric Viberta, b, c Denis Castaing ${ }^{a, b, c}$ \\ a AH-HP Hôpital Paul Brousse, Centre Hépato-Biliaire, \\ bInserm, Unité 785, \\ c Université Paris-Sud, UMR-S785, Villejuif, France
}

Even today, oncological surgery implies the resection of all malignant tissue. Incomplete resection, of local or distant disease, is not used and may be harmful for the patient [1]. Because of this assertion and due to the mortality associated with hepatectomy, 50 years ago the presence of liver metastases was a palliative situation [2]. During this era, with great daring some surgeons proposed to operate on colorectal liver metastases. The metastatic dissemination of malignant cells into the liver only via the portal vein justified this aggressive attitude [3]. Hence, patients with extra-hepatic metastases of colorectal cancer, even when resectable, were not considered suitable for surgery. Now, with the exception of involved celiac lymph nodes, there is no contraindication to resection of all colorectal metastases if they are all macroscopically resectable [4]. Even peritoneal carcinomatosis is not a contraindication of resection of colorectal liver metastases anymore, with a 3-year overall survival of more than $40 \%$ [5].

Evolution of these therapeutic attitudes was due to the major improvements of medical oncology, radiology and surgery [6]. Oncosurgical strategies in metastatic disease are now always the result of a debate that implies all these specialties. Thanks to this association, surgery of liver metastases is now potentially feasible even in patients with systemic disease. It is the improvement of chemotherapy and targeted treatments that allows to treat patients in this situation. The role of chemotherapy is to select patients with resectable macroscopic liver metastases and to possibly treat microscopic systemic malignant cell dissemination. The difficult work of the radiologist is to detect the (sometimes microscopic) residual tumors, so the surgeon can assess whether surgery is feasible and thus avoid a laparoscopy or worse, an explorative laparotomy.

The interesting paper of Kollmar et al. [7] in the last issue of ONKOLOGIE very well summarizes the development of liver surgery in patients with liver metastases from gynecological cancer. In this work, they report on 43 patients that have been operated on for liver metastases of gynecological cancers between 2000 and 2007. More than $80 \%$ of these patients re- ceived chemotherapy before and after laparotomy, which allowed a curative liver resection in 30 patients. Except for 3 patients, all had metachronous disease with a mean delay of more than 6 years after resection of the primary tumor. There was no postoperative mortality after hepatectomy and only 4 patients had positive margins.

Liver metastases of breast cancer represented the major subset of the patients of this series (62\%). In this group, resection of liver deposits clearly improved the outcome with a 5-year overall survival of $50 \%$ compared to a median of survival of 7.4 months without resection. The small number of patients treated for liver metastases of ovarian $(n=8)$ or uterine cancer $(n=8)$ makes it difficult to interpret the results that showed no clear advantage of liver surgery compared to explorative laparotomy. It is a pity that the results have not been stratified according to the primary tumors.

The major interest of this paper is to describe the results of a series of patients recently treated for liver metastases of breast cancer and within a relatively short period (2000-2007). In fact, several series of this pathology are now available but all of these have covered long periods of inclusion. For instance, the two largest series include 69 and 108 patients, but the patients included were operated on between 1988 and 1999 [8] and 1984 and 2004, respectively [9].

Even though the present series of patients is small, it demonstrates of the end of a dogma. Surgical therapy now plays an important role in the treatment of cancer patients with apparent systemic disease spread, as in metastatic breast cancer. Approximately $50 \%$ of breast cancer patients develop metastases [10] and this series confirms that patients with liver metastases from breast cancer will probably more often be offered surgery. The benefit of neoadjuvant chemotherapy has been demonstrated only recently in patients operated for resectable colorectal liver metastases [11], soon the benefit of adjuvant surgery in patients treated by chemotherapy for metastases of breast cancer will become apparent.

\begin{tabular}{ll}
\hline KARGER & @ 2008 S. Karger GmbH, Freiburg \\
Fax +497614520714 & Accessible online at: \\
$\begin{array}{l}\text { E-mail Information@Karger.de } \\
\text { www.karger.com }\end{array}$ & www.karger.com/onk \\
&
\end{tabular}

Denis Castaing, M.D.

Hôpital Paul Brousse, Centre Hépato-Biliaire

12 Avenue Paul Vaillant Couturier

94804 Villejuif Cedex, France

Tel. +33 145 59-3000, Fax -3857

denis.castaing@pbr.aphp.fr 


\section{References}

1 Scheele J, Stangl R, Altendorf-Hofmann A: Hepatic metastases from colorectal carcinoma: impact of surgical resection on the natural history. Br J Surg 1990;77:1241-1246.

2 Jaffe BM, Donegan WL, Watson F, Spratt JS, Jr. Factors influencing survival in patients with untreated hepatic metastases. Surg Gynecol Obstet 1968;127:1-11.

>3 Koch M, Weitz J, Kienle P, Benner A, Willeke F, Lehnert $\mathrm{T}$, et al.: Comparative analysis of tumor cell dissemination in mesenteric, central, and peripheral venous blood in patients with colorecta cancer. Arch Surg 2001;136:85-89.

4 Elias D, Ouellet JF, Bellon N, Pignon JP, Pocard M, Lasser P: Extrahepatic disease does not contraindicate hepatectomy for colorectal liver metastases. $\mathrm{Br}$ J Surg 2003;90:567-574.
5 Elias D, Benizri E, Pocard M, Ducreux M, Boige V, Lasser P: Treatment of synchronous peritoneal carcinomatosis and liver metastases from colorectal cancer. Eur J Surg Oncol 2006;32:632-636.

6 Poston GJ, Adam R, Alberts S, Curley S, Figueras J, Haller D, et al.: OncoSurge: a strategy for improving resectability with curative intent in metastatic colorectal cancer. J Clin Oncol 2005;23:7125-7134.

7 Kollmar O, Moussavian MR, Richter S, Bolli M, Schilling MK: Surgery of Liver Metastasis in Gynecological Cancer - Indication and Results. Onkologie 2008;31:375-379.

-8 Pocard M, Pouillart P. Asselain B, Falcou MC, Salmon RJ: Hepatic resection for breast cancer metastases: results and prognosis (65 cases). Ann Chir 2001;126:413-420.
Adam R, Aloia T, Krissat J, Bralet MP, Paule B, Giacchetti $\mathrm{S}$, et al.: Is liver resection justified for patients with hepatic metastases from breast cancer? Ann Surg 2006;244:897-907; discussion 907-898.

0 Zinser JW, Hortobagyi GN, Buzdar AU, Smith TL, Fraschini G: Clinical course of breast cancer patients with liver metastases. J Clin Oncol 1987;5: 773-782.

1 Nordlinger B, Sorbye H, Glimelius B, Poston GJ, Schlag PM, Rougier P, et al.: Perioperative chemotherapy with FOLFOX4 and surgery versus surgery alone for resectable liver metastases from colorectal cancer (EORTC Intergroup trial 40983): a randomised controlled trial. Lancet 2008;371: 1007-1016. 